\title{
An African woman's dilemma in The Secret Lives of Baba Segi's Wives: A bosadi perspective on the challenges and pains of infertility
}

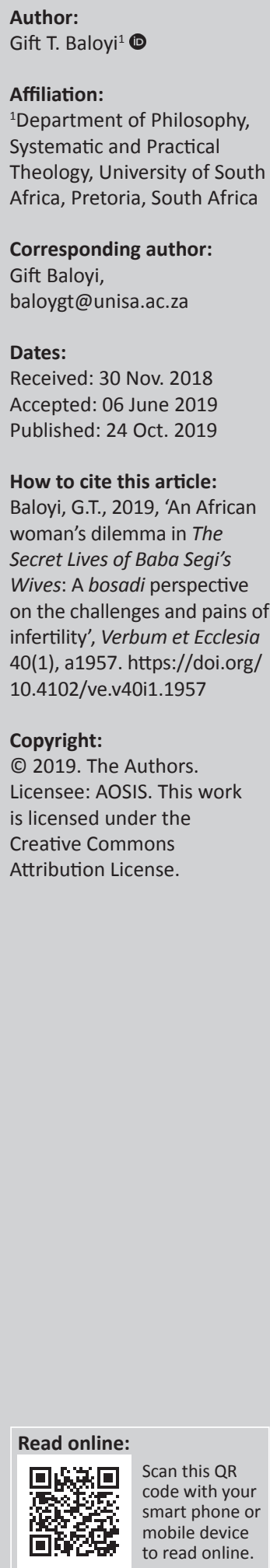

This article deals with the predicament faced by an African woman in novel, The Secret Lives of Baba Segi's Wives. In this fascinating novel, Lola Shoneyin wrestles with several cultural pressures in marriage, which are also prevalent among black women in South African communities. The article grapples with dilemmas, challenges and unbearable pains of women who are often blamed for infertility in marriage, without a consideration of the fact that medical problems leading to infertility are non-discriminatory in nature. It argues that: (1) women's sexuality is viewed with a patriarchal prejudice; (2) the referral of infertile woman as worthless, which in essence reveals the quality of their inter-subjective relationship, depicts men as the agents and women as the objects in marriage; and (3) that the order of the African family unit is deeply constructed on gender lopsidedness. In the end, Masenya's notion of bosadi (womanhood) is employed to indicate the significance of the way in which a woman was created by God to be a fully active human.

Intradisciplinary and/or interdisciplinary implications: Even though this article is written from a practical theological point of view, its nature has implications for other disciplines in the area of social sciences. The article approaches the question of gender from multidisciplinary angles.

Keywords: African women; bosadi (womanhood); empathy; infertility; marriage; pastoral care; patriarchy; power dynamics.

\section{Introduction}

Shoneyin's (2011) novel, The Secret Lives of Baba Segi's Wives, narrates a family unit built on dishonesties and secrets, which kept the family together for a while. Although the novel relates a devastating secret in Baba Segi's polygamous house, the main focus in this article is on the trials faced by Bolanle (Baba Segi's fourth wife) and how she carried herself through it all. This novel is used as a case study in response to similar situations faced by many African women in different societies, especially in the South African context.

Empathy is employed as a guiding tool in unpacking Bolanle's challenges in her polygamous marriage. According to Riess (2017:74), 'empathy plays a critical interpersonal and societal role, enabling sharing of experiences, needs, and desires between individuals and providing an emotional bridge that promotes pro-social behaviour'. Empathy is defined as 'the ability to experience and relate to the thoughts, emotions, or experience of others' (Gentry, Weber \& Sadri 2007:2).

Empathy is fundamental in understanding people's experiences in professions such as psychology and pastoral care that involve helping others. People should be able to understand a situation as if they were personally experiencing such a situation, even when they would not be. The approach in this article is entirely empathic as encompassing both the cognitive and the affective domains. According to Strauss (2004; cf. Wlodarski 2015:232):

Empathy comes in different flavors. Psychologists have particularly distinguished cognitive from affective components of empathy. The cognitive aspect of empathy is awareness of another person's feelings; the affective aspect is an emotional reaction to another's feelings, in particular, 'an affective response more appropriate to [their] situation than to one's own. (Strauss 2004:434)

In other words, the affective component can be summarised as, 'I feel what you feel', and the cognitive component as, 'I understand what you feel' (Wlodarski 2015:232). This model helps one to be aware and to make sense of another person's feelings and experiences, which become 
prerequisites for a practical theological response. Empathy helps oneself to comprehend and experience sorrow through the sorrow of others. However, other scholars, such as Nussbaum (2001:327), remind us that it is not possible for one to become the same with the sufferer of pain. Nussbaum draws her argument from the idea of sympathy with understanding of the notion of empathy. She understands empathy to be that which 'involves a participatory enactment of the situation of the sufferer, but always combined with the awareness that one is not oneself as the sufferer' (Nussbaum 2001:328). Nussbaum in her argument on the concept highlights empathy as an essential ingredient of humanity and a necessity for social justice.

With such an aspect in mind, empathy encompasses the experience of being moved by, or responding in tune with, another person's experiences or feeling, and this reflects elements of pastoral care. This approach will help unpack the novel and connect with the realities of women on the ground.

\section{Problem statement}

In many (South) African communities, women are seen as objects in marriage, while their male counterparts are seen as agents. They are even blamed for challenges related to infertility because in such patriarchal communities, men cannot be infertile. It is as if there is a lot wrong with their wombs, without looking at the potential defects of manhood. That is the case, even though medical tests can reveal that it is not a woman who is infertile. This article therefore grapples with dilemmas, challenges and unbearable pains of women who are often blamed for infertility in marriage, without a consideration for the fact that medical problems leading to infertility are non-discriminatory in nature.

\section{The scene behind the secret lives}

In this fascinating novel, The Secret Lives of Baba Segi's Wives (2011), Lola Shoneyin deals with several African cultural pressures in marriage; although her text is located within the Yoruba of Nigeria, the challenges raised are prevalent in other societies (including South Africa) as well. Iya ${ }^{1}$ Segi, Iya Tope, Iya Femi and Bolanle are married to one man, Ishola Alao known as Baba Segi (this name shall be used throughout this work). As the opening section commences, we find that Baba Segi's youngest and the only formally educated wife, Bolanle (fourth spouse), is causing him worries through her alleged failure to conceive. Baba Segi is, after all, the father of seven children with his first three wives and because he is no slacker in his marital sexual obligations, something needs to be done to address Bolanle's condition. Bolanle scoffs at traditional healers and remedies, so his teacher (Baba Segi's celibate mentor) advises the

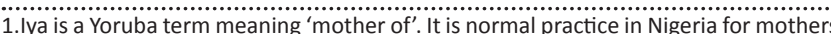
to be known as 'ly', follow ' by the name of their first child (see Shoneyin 2011). the However, this way of addressing women as 'mother of is not just a Nigerian practice but a practice embraced by all African communities. Such is also prevalent within the South African context (among the various vernacular languages); mothers are known as 'Iya' followed by the name of their first child. troubled husband to take his modern, sceptical wife to the University Hospital for tests. This is the process that will in due course unleash a torrent of unforeseen consequences. Baba Segi is confident in his virility and stature as a patriarch.

The apparent barrenness of Bolanle, his beloved and educated fourth wife, causes him much concern. His three other wives had, unbeknownst to him, solved the problems of childbearing in their own unique, crafty ways. But Bolanle insists that she and her husband take a test. He learns that he is, indeed, not as virile as he had claimed. Baba Segi recalls the day they met; he thought to himself: the gods have sent her to me ... as his eyes rested on Bolanle's bosom. He had then asked her: 'Now that you and your friend have finished university, are you going to marry a man who will look after you?' And she had replied 'When I find one' (Shoneyin 2011:6). So, along the way, she does make it clear that she has made an honourable commitment in which she said: 'I chose this family to regain my life, to heal in anonymity', she says, 'and when you choose a family you stay with them'. However, her friends challenged her choice to marry in polygamous settings. However, in him, Bolanle saw 'a large but kindly, generous soul' (Shoneyin 2011:17) beyond being a polygamist. ${ }^{2}$ The most powerful of the spouses is Baba Segi's first wife, Iya Segi, whose daughter Segi is the eldest of the household's children. Iya Segi firmly believes that Bolanle 'wants our husband to cast us aside as the illiterate ones', but also that 'these educated types have thin skins' and that, if 'poke[d] [...] with a stick, she will fly away and leave our home in peace' (Shoneyin 2011:52-53). Things come to a crisis on the morning when Baba Segi first takes the new wife (Bolanle) to the hospital for the fertility test. However, Iya Segi declares to the other two wives that 'she will destroy our home. She will expose our private parts to the wind. She will reveal our secret. She will bring woe' (Shoneyin 2011:55).

Because of this, a first serious attempt to expel Bolanle is immediately hatched (which brings the point of how innocent people suffer as compared with those who find their ways through crafty means). Despicable substances are planted around the house; the other wives claim to have discovered by good fortune that Bolanle was attempting to cast a fatal spell over Baba Segi's life. But Bolanle's calm logic disproves the false accusation. Moreover, the food had been poisoned in a plot by Iya Segi and Iya Femi to get rid of the detested Bolanle. Instead, it is Segi (the first wife's daughter) who lies on the floor in agony, her father on his knees beside her, pleading to the unconscious girl to 'tell the gods you want to stay here with me' (Shoneyin 2011:159). At this time, the medical investigators of Bolanle's apparent barrenness have invited Baba Segi to come in for a sperm test. Before they reveal the results to him, they ask him to bring one of his other wives to the hospital with him.

2.Polygamy (from Late Greek polygamia, 'state of marriage to many spouses') is the practice of marrying multiple spouses. When a man is married to more than one wife at a time, sociologists call this polygyny. 
Profoundly shaken by her daughter's condition, Iya Segi volunteers to be the one at the hospital, and the doctor reveals to Baba Segi: the 'father' of seven children is, in fact, sterile. The news shatters him. At home that evening, deeply drunk, he denounces his unfaithful wives; in the midst of the dreadful scene, Segi releases her last breath. Just after the quick Muslim funeral, Baba Segi summons his wives and says: 'It is not every day, that a man finds out his children are not his own' (Shoneyin 2011:240). He tells them they are free to go. At this point, the bereaved and utterly chastened Iya Segi intervenes: 'Who is the father of the children?' she asks him (Shoneyin 2011:241). She insists that it is he, Baba Segi, the man who has lovingly and generously brought up and supported these seven (now six) children, who is their only real father. She begs Baba Segi to keep them and to allow the wives to stay, having acknowledged earlier that it was she who had instigated the plan for the other two wives to seek impregnation by other men as she had done.

But this secret, she says, must be kept within the family. Baba Segi accepts this suggestion. However, Bolanle announces her intention to leave and restart life on her own elsewhere. She remarks quietly to herself, 'I will remember Baba Segi. I won't miss him but I will remember him. [...] Perhaps on some days', she adds, 'I will remember him with fondness [having] learnt many things from the years I spent under his roof' (Shoneyin 2011:244). So, this concludes the sometimes harrowing and sometimes poignant account of the numerous dark secrets of Baba Segi's wives. I leave Shoneyin's narrative as Bolanle declares her resolve to meet the challenges of her new, post-marital life with hope, for she is back 'in the land of the living' after her years of depression, 'and the world is spread before (her) like an egg cracked open' (Shoneyin 2011:245).

\section{A 'synopsis of an African woman's dilemma'}

The Secret Lives of Baba Segi's Wives is an example of the unbearable pain African women are subjected to on the basis of childlessness. It is unbearable in that it locates women to a level beneath the human. In the account above, a woman is expected to solve the problem of childbearing in her own unique and possibly crafty way. Bolanle is at the centre of what is claimed to be a societal norm, that is, any married woman should give birth. Bolanle thus struggled to face her own people and community. Moreover, her barren state is used as a means to psychologically control her. While women face societal criticism and mockeries because of childlessness, men struggle to confront that which threatens their social standing and the power of their manhood. However, researchers such as Greil Slauson-Blevins and McQuillan (2010:146) indicate that 'while wives are pitied, husbands are teased', but in other societies it is the opposite. Baba Segi made it very clear to Bolanle that her barrenness brought shame on him in society. Baba Segi asked Bolanle what 'was wrong with her womb' (Shoneyin 2011:84) and his own ugly warning to Bolanle was that: 'If your father has sold me a rotten fruit, it will be returned to him' (Shoneyin 2011:84). It is on this basis that feminist theologians, such as Ruether (2002), argued correctly that a:

[W]oman's body - her reproductive process - becomes owned by men, defined from a male point of view. Women are seen as reproducing children and producing cooked food and clothes for men. (p. 64)

In agreement with the description offered by Ruether, Baba Segi saw nothing valuable in Bolanle except that she is a woman whom he married to give birth. This despite his earlier feelings when they met, as Baba Segi did not forget his patriarchal position.

Her educational qualifications meant nothing to him as the patriarch of the household (cf, Walby 1990). Could it be that the physiological appearance of women exposes them to much exploitations by virtue of their sexuality? According to Eze (2015):

Baba Segi does not feel the pain of his wife's supposed barrenness because it disturbs his wife, but because it apparently makes people think that he is no longer a man. (p. 319)

In any case, he would not feel for her because she is under his authority. In his mind, she is his subordinate after all, an object for him to do with whatever would please him. Ruether (2002) argues more on the control over a woman's womb in that:

The ... subjugation of woman is the subjugation of her womb, the subjugation of access to her body, so that she should not ... explore the pleasures of her own body but that her own body and its fruit should belong first to her father, who would sell her or trade to her husband. She must be delivered as undamaged goods, duly inspected ... (p. 219)

Once again, Ruether gives a precise analysis, which I think reflects the character of Baba Segi, especially in his ugly warning to Bolanle that, 'If your father has sold me a rotten fruit, it will be returned to him' (Shoneyin 2011:84). In Baba Segi's mind, Bolanle could be a damaged commodity, which was never duly inspected. But then, who was to inspect Bolanle? Her father? This sounds more like a patriarchal play in a form of controlling her sexuality. Furthermore, Baba Segi's use of the word 'sold' reduces Bolanle to an object or commodity, which one can buy and return back to the seller if it fails to deliver according to the expectations ${ }^{3}$. This brings to light the wrong and misplaced conceptions that most African men have on lobola. Baba Segi's focus was on getting what he wanted and not sympathetically responding to the situation faced by his fourth wife. Bolanle's supposed barrenness made Baba Segi refer to her as a 'thing', which in essence reveals the quality of their inter-subjective relationship. This portrayal of

3.On the same note, Hollos \& Larsen (2008:161) indicate that there is a close relationship between bride price and rights over children, which is indicated in some places by the common practice of payment of bride price in instalments - for some places by the common practice of payment of bride price in instalments - for example, following the successful birth of a first, second and third child. In the case of infertility, the husband is entitled to the repayment of the bride wealth, indicating that he did not receive the goods that he paid for. This is probably one of the reasons why the essence of womanhood is mostly defined by her capacity to be a mother (Widge 2002:60). Although Widge (2002:61) indicates, the ideology of motherhood differs according to the sociocultural context, ethnicity, and class', motherhood has sociologically be given connotations of respect and power. 
her as a 'thing' depicts Baba Segi and of course other men who think this way as authority and agents over women. This is part of how power dynamics over women are played in households, especially in polygamy. For example, Kanyoro (2001:50) argues that 'polygamy thrives in patriarchal cultures which believe in the superiority of male persons'. Baba Segi's case shows to a certain degree that children (especially males) are a source of power for men in particular. Therefore, infertility for males (particularly in the African context) remains a threat to their social standing (cf. Mbiti 1969; Waruta \& Kinoti 2013). A similar point is further argued by Mason (1993) in that giving birth stands as a signifier of manhood and the opposite is perceived as failure of masculinity or manhood. Mason et al. (1993) point out that failure of masculinity in being unable to procreate is seen as part of the conflation of fertility with impotence.

Hanna and Gough (2015:6) indicate that some women voluntarily protect their infertile husband given the stigma that is attached to male infertility. They point out that 'women often shoulder the "blame" for fertility problems even when male-factor infertility has been diagnosed'.

Surprisingly, in a case where a woman is medically found to be infertile, she is exploited, called names and subjected to divorce and other acts that may denigrate the essence of her womanhood (cf. Dyer et al. 2002:1664-1665; Oduyoye 2001). Furthermore, the oppression of women presents itself in different forms and shapes in various situations. The first three wives were consciously or unconsciously propagating the agenda of Baba Segi's patriarchy over Bolanle's supposed barrenness. The covering of Baba Segi's infertility becomes a weapon to frustrate Bolanle. What this submits is that the success of Bolanle's marriage was determined by her ability to give birth. One may wonder as to whether the societal cultures truly afford women the dignity as humans who are not a means to another's ends, but ends in themselves. Somehow, society has been shaped in such a way that women are recognised as owing their lives to men and culture, such that a married woman receives better treatment even by society than one who is unmarried.

Here, one sees the dehumanisation and subjugation of women in many phases and that a male superior uses a female as an object for his own benefits. Such is power dynamics that is also found in the institution of marriage.

\section{Power dynamics over women in marriage}

Stan Chu Ilo (2006) indicates that African societies have embraced incorrect perceptions that through marriage a woman earns respect and dignity. What this insinuates is that outside the institution of marriage, a woman remains a nobody. But within the marriage itself, that respect is actually conditional; that is, until a child is born, a woman will not be respected fully as 'Iya'. In Shoneyin's novel, Bolanle is addressed by her name, while the other three are addressed as 'Iya' (mother of). Already, there is a challenge of failing to understand that the use of the term 'Iya' has power dynamics in the lives of women. It contributes in the process of disempowering and undermining women and the essence of being human with full rights and dignity. 'Iya' becomes a determinative title for women's freedom in society today, and where the title 'Iya' is not applicable, a woman suffers greatly. There is absolutely no consideration of a situation where the woman could lose her child, yet they had suddenly lost their identity and came to be referred to as someone's mother.

Understanding women's dignity by virtue of marriage is highly problematic, as it portrays marriage to be the only institution that confers dignity and respect to women (cf. Segalo 2013:1-10). In reality, this institution is also known to be the first among others in constructing norms and systems that enslave women. Although other people perceive unmarried women as free from male supremacy and control (Osiek 2006:832-834), there seems to be a dynamics of control over women by virtue of gender and patriarchal ideologies, that is, they are inferior to men notwithstanding their education, cultural affiliation, class and religion. Gender remains one of the most significant factors in shaping the power dynamics in households.

\section{For Mothlabi, as cited by Kobo (2016:2):}

$[P]$ ower and authoritarianism, as social structure in which some people are regarded as having the right to exercise control over the lives of others by virtue of the position they hold within the social structure. He contends that such is by no means limited to political structures but is also found in a home situation where allusion is made to Pauline's text: 'the husband is to be the head of his wife. (Eph 5:23)

Similarly, Robert Dahl (1957:202-203) gives what he calls an 'intuitive idea of power' according to which 'A has power over $\mathrm{B}$ to the extent that he can get $\mathrm{B}$ to do something that $\mathrm{B}$ would not otherwise do'.

In marriages in cultural contexts that are similar to that of Baba Segi, a woman is regarded as a property of her husband who can do anything with her, including retuning her to her parents should she find no favour in his eyes. Both in marriage and outside, she is under the subjective power of a male patriarch. Similarly, Stan Chu (2006) captures such argument in that it is through marriage that a woman gains dignity; hence, she is someone because she is married and she is nobody outside marriage. This way of understanding is quite misleading, as it paints women as subordinates and commodities of men. But of course there is a history of gender inequality, which established itself as a norm in different spheres of life. Redding in Meader and Wiesner-Hanks (2006:545) points out that a girl or woman is not considered an adult, capable of authority even over her own person, which gives more power and authority to men over her life.

While women are not considered as adults, 'the young male is taught to identify with the male sphere as higher than the 
female sphere ...' (Ruether 2002:63), and begin to establish themselves as persons of power and authority over women in society. This highlights the manner in which some male individuals have capitalised on such sexist and patriarchal norms as means of exercising power over women.

Men therefore inherit social norms that negatively affect women even though the mechanisms of control vary with their social context. Tichenor (2005:193) points out that, 'within marriage, men's power over women has been linked to and legitimated by their role as breadwinners ...' and many other norms or aspects that go with the sociological perceptions of masculinity.

In other words, such norms become part of how they define themselves and how they want to be known by society (cf. Haavind 2002:7-12). Linda Lindsey (2015:3) describes 'patriarchy, by definition, exhibits androcentrism male-centred norms operating throughout some social institutions which become the standard to which many persons adhere'. She argues further that sexism is reinforced when patriarchy and androcentrism are combined to perpetuate beliefs that gender roles are biologically determined and therefore unalterable (2015:3). Patriarchy has the potential to propose a sequence of non-being in the identification of women on the basis of their sexuality.

As a strategy to disempower women, patriarchy maintains the order of creation in that 'the male intellect rules over the female psyche and the distinction of their sexes, which for them (males), signifies that a woman is different from a man' (Børresen 1995:171). Others, such as Thomas Aquinas, argue that the manner in which a female body was formed is interpreted in this sense of subordination (Børresen 1995). In Thomas Aquinas' thoughts, man's domination over woman is based on the primacy of the male sex, in the sense that it is considered as more perfect. For Aquinas, as for Augustine, a woman is ontologically (per definition) inferior; man is, by nature, superior. She must assume an auxiliary role in conformity with the inferiority of her body (see Parsons 2011:95). This system of patriarchy reveals itself as '... the power relationships by which men dominate women, and to characterise a system whereby women are kept as subordinates in a number of ways' (Bhasin 2006:3). The power dynamics are done or at least displayed through institutions such as the academy, the church and the family, each of which justifies and reinforces women's subordination to men (Millett 1977:35).

\section{Masenya's notion of bosadi (womanhood)}

Madipoane Masenya (ngwana' Mphahlele) is a South African woman theologian who writes on different issues pertaining to the life or well-being of women. She does so by reflecting from the Bible, thereby using bosadi notion to foreground her methodological approach. In her employment of the concept of bosadi, in several published works (1996, 1998,
$2005,2009,2011)$, she critiques culture and texts in a way that affirms women as full humans. In defining the notion of bosadi, Masenya (2005) states that:

The Northern Sotho word bosadi (womanhood) is an abstract noun derived from the word mosadi. The latter has the following meanings: 'woman', 'married woman', 'wife'. The word mosadi comes from the root-sadi, which denotes 'womanhood'. The word bosadi may similarly be translated as 'womanhood' or 'private parts of a woman'. The word mosadi (woman) is also used in other African-South African languages, such as the Nguni (umfazi), Venda, (musadzi), Xitsonga (wansati), and Setswana (mosadi), a fact revealing the basic commonalities of language and experience among the various indigenous people of South Africa. (p. 183)

From the definition above, Masenya opts for bosadi as opposed to mosadi for her gender framework. She points out that mosadi '... can, depending on the context, be used in a derogatory sense' (2011:81). In the same work (Masenya 2011), she argues that:

The ... (Mosadi) ... reveals the bias that the African culture has against women as seen in the following usage: A man who is referred to as mosadi, is despised in one way or other. The same word however, may be used for praising a woman as in: O mosadi! Literally, you are a woman, meaning you deserve praises, you have acted in a womanly (sesadi) way!

... the word bosadi describes what it means to be a woman in the African-South African culture. In the bosadi approach, the word mosadi, unlike in the traditional sense with its notion of mosadi as a married woman, is used to refer to 'woman', irrespective of her marital status. (pp. 81-82)

Some societal understanding regarding the concept of bosadi is that it calls for expected roles involving nurturing, selfsacrifice, homemaking, availability and subordination. This was observed in the case of Bolanle, where her role as a married woman was defined and tested in her ability to give birth. By virtue of her apparent bareness, she was no longer suitable to be called a woman because of the infertility challenges. Such understanding relegates women to the level of being dominated and weakness. A similar analysis is given by Ruether (2002:81) in that, because of her gender, she is regarded as '... inferior in body (weaker), inferior in mind (less capable of reasoning), and inferior morally (less capable of will and moral control)'. For Masenya (2005:747), the whole method of the bosadi enables 'women to read the Bible in a way which affirms them'. In the context of this article, bosadi refers to the significance of the way in which a woman was created by God to be a full and active human. This means to appreciate her value as merely a human being beyond her gender. In support of Masenya's understanding is Gyekye (1998) who believes that:

$[T]$ o enjoy a human being means you should recognize the other person as a fellow individual whose worth as a human being is equal to yours and with whom you undoubtedly share basic values, ideas and sentiments. Thus, the main intent of the maxim is to point out the worth of a human being and the respect that ought to be given to her by virtue of her humanity. (pp. 25-26) 
The inability to recognise Bolanle as a real woman by her husband is a failure to acknowledge her worth as a human being. To be human means more than just the physical shape or form of a human being. Whether Bolanle is medically capable of giving birth, or not, the question of worth in her capacity as a woman supersedes societal perceptions about the definition of woman.

To arrive at a position of recognising a human being beyond gender constructs or ideologies would equally mean recognising a woman as a human being of worth. Infertility, and other challenges faced by Bolanle and other African women, should not be read as determinative factors to the status of bosadi. In other words, bosadi is not and should not be defined in terms of one's ability to give birth, but rather in terms of being created in the image of God. A similar argument is raised by Musopole (1994:178) in that, 'the glory that is human has to be expressed concretely in order to be realized by oneself and acknowledged by others'.

Karl Bath (1961:118) identifies man (humanity) as essentially comprising male and female. From his argument, we have no access to a common human nature, beyond male and female. Thus, there is no human being who is not 'necessarily and totally man and woman'. In other words, man never exists as such, but always as the human male or the human female. From Bath's point, I maintain that to be female and male is to be human in full and where respect of humanity ought to begin. This is in line with the bosadi hermeneutic, as it stands above as a method of humanity of women. Even in the context of those women who chose not to get married or to voluntarily not have children for many reasons, their bosadi has dignity as full human beings and that is not forfeitable and indestructible. This describes women as having equal dignity, being of equal worth and value (see Dreyer 2007a:1513; cf. Sonko 1994:397-411). When we define women as true and complete humans on the basis of fertility, we affect the quality of their humanness that supersedes their fertility.

This methodological framework gives a new lens of reading and understanding women in a manner that represents them as human beings. That is, when we see women, we should understand them as human beings and far beyond our sociological expectations attached to being a woman. Masenya (2015:78) states that 'issues concerning patriarchy, particularly in its multifaceted forms in differing women's contexts need to be treated as a matter of urgency in our Biblical interpretation endeavour'. Indeed, however, Phiri (2007:155) adds that the reading of the Bible that empowers women should begin by identifying the contextual challenges that oppress female child marriage, exclusion from education and other forms. In this way, our approach to issues of women will have relevance and be able to liberate women from evil and life challenges. The bosadi looks deeper into the systems that are demeaning and dehumanising towards women by developing an awareness model that then helps people to view women in a manner that pleases God from creation.

\section{Behind the fiction and the urgency of women's stories}

Infertility has been regarded as women's problem or condition by some people (see Masenya 2003; Segalo 2013). Although infertility is traditionally situated within the compass of medicine, it has a greater influence on how social construction understands the phenomenon with regard to both men and women. Because this phenomenon is mostly gender defined (Johansson, Hellstrom \& Berg 2011:5; see, Webb \& Daniluk 1999), society shifts the blame for being childless onto women (Dyer et al. 2004:960; Savage 1992). This is so, probably because a woman is the one who carries and gives birth to a child.

In some African societies, the essence of womanhood is mostly defined by her capacity to be a mother (i.e. to bear her own child) (Widge 2002:60). Although 'the ideology of motherhood differs according to the sociocultural context, ethnicity, and class' (Widge 2002:61; cf. Makinde 2004:164-174), motherhood has sociologically been given connotations of respect and power with conditions attached to it. By conditions in this regard, I mean the limitations to which these qualities can extend. For example, some people recognise a woman as respectable and really strong as mother on the birth of a child. In a case where a child is not born, they are often victimised and called names. Another example of this is observed in the case of Bolanle in the novel The Secret Lives of Baba Segi's Wives (Shoneyin 2011). It would appear that the qualities of respect are placed on women for a short period, until they pass the test (i.e. proving their womanhood through marriage and motherhood), and then it becomes permanent. So, giving birth is one of the major criteria society employs to measure the worth of women. Should a woman get married and give birth first to qualify for the status of respect? If this is not a new model of patriarchy, then oppressive systems unfold in multiple dimensions against women. Widge, as cited by Segalo (2013), argues that:

$[B]$ ecause she is defined by her fertility, it can then be assumed that a woman internalises the motherhood role to the extent that if she is infertile or childless, she feels worthless. (p. 4)

But feeling 'worthless' has to do with the thought of being a 'failure' from the constructs of society and the level of comprehension on the meaning and role of women in society.

Segalo (2013:4) reminds us that because children play a very important role in many societies, childlessness is socially regarded as a crisis for couples (cf. Hanna \& Gough 2015:2). Put differently, the inability to procreate, regardless of one's medical status, constitutes a major life crisis and does place women's credibility at stake (cf. Mikkelsen, Madsen \& Humaidan 2013; Throsby \& Gill 2004:335). Infertility as a medical phenomenon is not a female problem; it is a human problem and must be understood as such. The fact that males are defined and categorised as humans, like females, indicates that they are not exempted from the possibility of being infertile. 
According to Hollos and Larsen (2008:161), 'most African societies have been found to be strongly pronatalists ${ }^{4}$ who mandate parenthood. In this context, infertility is especially problematic and is not considered a matter of choice'. Most involuntary childless women suffer personal grief and frustration, social stigma and exclusion as they are seen to be fruitless in their own societies (cf. Seibel 1997:181-183). They are blamed for reproductive mishaps, and in some instances, infertility constitutes grounds for divorce, causing a woman to lose access to her livelihood. With this in mind, it confirms Rosemary Ruether's (2002:64) argument that 'women's sexuality and their wombs are being controlled', either by those subscribing to pronatalism ideology or by patriarchs to advance their own agenda. For those who subscribe to religious beliefs, such as Christianity and African traditional religion, a child is acknowledged as a gift from the supreme God and that he is in control of the human species in full.

Masenya (2003:102) argues, 'Women's sexuality is often defined and controlled by men both in the church and in the households. Female bodies become sacrifices at the altars of male power and pleasure'. The level in which some societies understand women as sexual objects whose role is to satisfy men's sexual desire and never about how they (women) feel is problematic.

\section{Conclusion}

The experiences of women go beyond biological and cultural understanding. There are undeniably biological sex differences between men and women, but these distinctions do not have to become the basis of a sexual hierarchy in which men are dominant. Human beings, that is, men and women, share a common human nature, characterised by reason and moral conscience. It is not a gender question, but that of being human, guided by moral conscience.

The consequences of infertility in most rural communities continue to subject women to severe subjugation (see Segalo 2013). They suffer from stigmatisation and ostracism at the hands of their in-laws, other women, their husbands and the society. For some of those who are in practical theology and other human caring fields (psychology, social work, etc.), empathy remains one of the important tools in the process of understanding other human challenges. It is through empathy that caregivers are able to get into other people's shoes, comprehend and be able to journey with them to a positive outcome.

This means that we cannot continue to bemoan the socialisation we have had when the lives of women are

4.Laura (2012:33-54) defines pronatalism as a powerful ideology and set of beliefs that goes back many generations... it is an attitude or policy that is pro-birth, that encourages reproduction, that exalts the role of parenth that is pro-birth, that encourages reproduction, that exalts the role of parenthood (cf. Brown 2002) Historically, pronatalistic values have been driven by two motives: survival and power. Throughout human history, valuing fertility was necessary to ensure survival. For example, to ensure population growth in Roman times, ruler Caesa Augustus instituted the Augustan Laws, which rewarded people who had many children and penalised childlessness. At the heart of this is the ideology of childbearing and parenthood as desirable for social reasons and to ensure the continuance of humanity. at stake. Empathy should always play a significant role, especially in issues pertaining to the well-being of women in African societies. In addition, where systems of oppression are put in place to frustrate women, empathy becomes a helpful tool in dealing with such troubling practices. Even though it is difficult when solidarity among women cannot be reached, especially on issues concerning their lives and culture (Ortega 1995:22-23), a collective reflection and criticism on all issues posing a threat to women is crucial.

This will empower women to claim their rights to health and well-being (Witte \& Alexander 2012), as defined by women themselves, and their right to special attention to all health hazards that may arise out of their reproductive inabilities.

Segalo (2013) indicates that:

Women have stories that remain untold; many of the transcripts of their lived experiences remain hidden as platforms for their voices remain minimal. Various contexts such as the home, the church and the workplace to name a few remain spaces that conditionally accommodate women's agency. It is therefore crucial that as we embark on our scholarly pursuits we acknowledge and use a gender lens that takes seriously situated life experiences of women within various contexts. (p. 8)

An atmosphere should be created within which women's experience can be tackled to contribute to the forming and shaping of human consciousness and women's liberation.

\section{Acknowledgement Competing interest}

The author declares that he has no financial or personal relationships that may have inappropriately influenced him in writing this article.

\section{Authors' contributions}

The author is the sole contributor to this article.

\section{Ethical considerations}

This article followed all ethical standards for a research without direct contact with human or animal subjects.

\section{Funding information}

There was no funding received for this article.

\section{Data availability statement}

Data sharing is not applicable to this article as no new data were created or analysed in this study.

\section{Disclaimer}

The views and opinions expressed in this article are those of the authors and do not necessarily reflect the official policy or position of any affiliated agency of the authors. 


\section{References}

Barth, K., 1961, Church Dogmatics III, p. 4, T \& T Clark, Edinburgh.

Bhasin, K., 2006, What is patriarchy? Women unlimited, Kali, New Delhi.

Børresen, K.E., 1995, Subordination and equivalence. The nature and role of women in Augustine and Thomas Aquinas, Kok Pharos Publishing House, Kampen, the Netherlands.

Brown, J.A., 2002, 'In praise of good breeding: Pronatalism and immigration in the British print media', MA thesis, University of Wisconsin, Madison, WI.

Buis, E.R., 2011, 'Surviving transition in the Giyani district: The role of small-scale rura development projects in a period of rapid socio-political and economic change' PhD thesis, University of Pretoria, Pretoria.

Dahl, R., 1957, 'The concept of power', Behavioral Science 2, 201-215. https://doi. org/10.1002/bs.3830020303

Dreyer, Y., 2007a, 'Karl Bath's male-female order as asymmetrical theoethics', HTS 63(4), 1493-1512. https://doi.org/10.4102/hts.v63i4.265

Dreyer, Y., 2007b, 'Karl Barth's male-female order: A kingpin of dogmatic disparity', HTS 63(4), 1523-1547. https://doi.org/10.4102/hts.v63i4.266

Dyer, S.J., Abrahams, N., Hoffman, M. \& Van der Spuy, Z.M., 2002, 'Men leave me as cannot have children: Women's experiences with involuntary childlessness', Human Reproduction 17(6), 1663-1668. https://doi.org/10.1093/humrep/ 17.6.1663

Dyer, S.J. Abrahams, N., Mokena, N.E. \& Van der Spuy, Z.M., 2004, 'You are a man because you have children: Experiences, reproductive health knowledge and treatment-seeking behaviour among men suffering from couple infertility in South Africa', Human Reproduction 19(4), 960-967. https://doi.org/10.1093/ humrep/deh195

Eze, C., 2015, “"Feminist empathy: Unsettling African cultural norms" in The Secret Lives of Baba Segi's Wives', African Studies 74(3), 310-326. https://doi.org/ 10.1080/00020184.2015.1067996

Gentry, W.A., Weber, T.J. \& Sadri, G., 2007, Empathy in the workplace: A tool for effective leadership, Centre for Creative Leadership, New York.

Greil, A., Slauson-Blevins, K. \& McQuillan, J., 2010, 'The experience of infertility: A review of recent literature', Sociology of Health \& Illness 32(1), 140-162. $\mathrm{https}$ ///doi.org/10.1111/j.1467-9566.2009.01213.x

Gyekye, K., 1998, African cultural values: An introduction, Sankofa, Accra, Ghana.

Haavind, H., 2002, Kulturpsykologi, Bevegelser I livsløp [Cultural psychology narratives through the lifespan], Scandinavian University Press, Oslo.

Hanna, E. \& Gough, B., 2015, 'Experiencing male infertility: A review of the qualitative research literature', Sage Open 5(4), 1-9. https://doi.org/10.1177/21582440 15610319

Hollos, M. \& Larsen, U., 2008, 'Motherhood in sub-Saharan Africa: The social consequences of infertility in an urban population in northern Tanzania', Culture, Health \& Sexuality 10(2), 159-173. https://doi.org/10.1080/13691050701656789

Johansson, M., Hellstrom, A. \& Berg, M., 2011, 'Severe male infertility after failed ICSI treatment: A phenomenological study of men's experiences', Reproductive Health 8, Article 4, 1-7

Kanyoro, M.R.A., 2001, 'Endangered communal theology: African women's contribution to theology in the 21st century', in M. Dube \& J.N. Nyambura (eds.) Talitha Cumi: Theologies of African Women, pp. 158-180, Cluster Publications, Talitha Cumi: The
Pietermaritzburg.

King, L., 1998, 'France needs children: Pronatalism, nationalism, and women's equity', Sociological Quarterly 39(1), 33-52. https://doi.org/10.1111/j.1533-8525.1998. tb02348.x

Kobo, F., 2016, 'Umfazi akangeni ebuhlanti emzini ... A womanist dialogue with Black Theology of liberation in the 21st century', HTS Teologiese Studies/Theological Studies 72(1), 1-6. https://doi.org/10.4102/hts.v72i1.3268

Laura, C., 2012, The Baby Matrix: Why Freeing our minds from outmoded thinking about parenthood \& reproduction will create a better world, Live True Books.

Lerner, G., 1989, The creation of patriarchy, Oxford University Press, New York.

Lindsey, L.L., 2015, Gender roles: A sociological perspective, Routledge, London.

Makinde, T., 2004, 'Motherhood as a source of empowerment of women in Yoruba culture', Nordic Journal of African Studies 13(2), 164-174.

Masenya (ngwan'a Mphahlele), M., 1996, 'Proverbs 31:10-31 in a South African context: A (woman-hood) perspective', D. Litt. Et Phil. thesis, Pretoria.

Masenya, M., 1998, 'A Bosadi (womanhood) reading of Genesis 16', Old Testament Essays 11(2), 271-287.

Masenya, M., 2003, 'A Bosadi (womanhood) reading of Proverbs 31:10-31', in M.W. Dube (ed.), Other ways of reading: African women and the Bible, pp. 147-157, WCC, Geneva.
Masenya, M., 2005, 'An African methodology for South African sciences: Revisiting the Bosadi (womanhood) approach', Old Testament Essays 18(3), 741-751.

Masenya, M., 2009, “"For better or for worse?”: The (Christian) Bible and Africana women', Old Testament Essays 22(1), 126-150.

Masenya, M., 2011, 'The woman of worth in Proverbs 31: 10-31: Reread through a Bosadi (womanhood)', Lens (79-96). In Faix, Tobias, Wünch, Hans-Georg \& Meier, Elke (Hg.). Theologie im Kontext von Biographie und Weltbild. Marburg: FranckeBuchhandlung. (GBFE Jahrbuch, 3).

Mason, M., 1993, Male infertility: Men talking, Routledge, London.

Mbiti, J.S., 1969, African religion and philosophy, Heinemann, London.

McGrath, A.E., 2001, Christian theology: An introduction, Blackwell Publishers, Oxford.

Meader, T.A. \& Wiesner-Hanks, M.E., 2006, A companion to gender history, Blackwel Publishers, Oxford.

Mikkelsen, A., Madsen, S. \& Humaidan, P., '2013, Psychological aspects of male fertility treatment', Journal of Advanced Nursing 69(9), 1977-1986. https://doi org/10.1111/jan.12058

Millett, K., 1977, Sexual politics, Virago, London.

Musopole, A.C., 1994, Being human in Africa: Towards an African Christian anthropology, Peter Lang, New York.

Nussbaum, M., 2001, Upheavals of thought: The intelligence of emotions, Cambridge University Press, Cambridge.

Oduyoye, M.A., 2001, Introducing African women's theology, Sheffield Academic Press, Glasgow.

Ortega, O., 1995, Women's vision: Theological reflection, celebration, action, WCC Publication, Geneva.

Osiek, C., 2006, 'New testament teaching on family matters', HTS 62(3), 819-846. https://doi.org/10.4102/hts.v62i3.382

Parsons, M., 2011, Reformation marriage: The husband and wife relationship in the theology of Luther and Calvin, Wipf and Stock Publishers, Eugene, OR.

Phiri, I., 2007, Women, Presbyterianism and patriarchy; Religious experiences of Chewa women in central Malawi, Kachere Series, Zomba.

Riess, H.D., 2017, 'The science of empathy', Journal of Patient Experience 4(2), 74-77. https://doi.org/10.1177/2374373517699267

Ruether, R.R., 2002, Sexism and God-talk: Towards a feminist theology, SCM Press, London.

Savage, O.M.N., 1992, 'Artificial donor insemination in Yaounde: Some socio cultural considerations', Social Science \& Medicine 34, 907-913.

Segalo, P., 2013, 'Women, they too have story: Re-imaging the female vice and body', Scriptura Journal 112, 1-10. https://doi.org/10.7833/112-0-71

Seibel, M., 1997, 'Infertility: The impact of stress, the benefit of counselling', Journal of Assisted Reproduction and Genetics 14(4), 181-183. https://doi.org/10.1007/ BF02766105

Shoneyin, L., 2011, The secret lives of Baba Segi's wives, Serpent's Tail, London.

Sonko, S., 1994, 'Fertility and culture in sub-Saharan Africa: A review', International Social Science Journal 46(3), 397-411.

Stan, C.I., 2006, The face of Africa: Looking beyond the shadow, Author House, Bloomington, IN.

Strauss, C., 2004, 'Is empathy gendered and, if so, why? An approach from feminist psychological anthropology, Ethos 32(4), 432-457. https://doi.org/10.1525/ eth.2004.32.4.432

Throsby, K. \& Gill, R., 2004, 'It's different for men: Masculinity and IVF', Men and Masculinities 6(4), 330-348. https://doi.org/10.1177/1097184X03260958

Tichenor, V., 2005, 'Maintaining men's dominance: Negotiating identity and power when she earns more', Sex Roles 53(3/4), 191-205.

Walby, S., 1990, Theorizing patriarchy, Blackwell Publishers Ltd, Oxford.

Waruta, D.W. \& Kinoti, H.W., 2013, Pastoral care in African Christianity: Challenging essays in pastoral theology, Acton Press, Nairobi.

Webb, R. \& Daniluk, J., 1999, 'The end of the line: Infertile men's experiences of being unable to produce a child', Men and Masculinities 2(1), 6-25. https://doi. org/10.1177/1097184X99002001002

Widge, A., 2002, 'Sociocultural attitudes towards infertility and assisted reproduction in India', in E. Vayena, P.J. Rowe \& P.D. Griffin (eds.), Current practices and controversies in assisted reproduction, pp. 60-74, World Health Organization, Geneva.

Witte, J. \& Alexander, F.S., 2012, Christianity and human rights: An introduction, Cambridge University Press, Cambridge.

Wlodarski, R., 2015, 'The relationship between cognitive and affective empathy and human mating strategies', Evolutionary Psychological Science 1(4), 232-240. https://doi.org/10.1007/s40806-015-0027-3 